\title{
Social representations of alcohol use among women who drank while pregnant
}

\author{
Jane F Kelly*, Catherine L Ward \\ From 2014 Addiction Health Services Research (AHSR) Conference \\ Boston, MA, USA. 15-17 October 2014
}

A substantial number of women consume alcohol while pregnant, thereby putting their unborn fetus at risk for developing a fetal alcohol spectrum disorder (FASD) [1]. Despite the fact that some of the highest rates of FASDs in the world have been reported in the Western Cape of South Africa [2,3], little research looks at the experiences of pregnant women who drink and what influences their alcohol use. Gaining insight into the social and psychological processes that contribute to risky drinking during pregnancy will help in guiding interventions that aim to prevent prenatal alcohol use, thereby preventing the occurrence of FASDs $[4,5]$.

Using a qualitative approach, 15 semistructured interviews were conducted in a Western Cape community with women who consumed alcohol during their pregnancy, and two focus group discussions with community members. Data collection aimed to elicit how these women and members of their community construct and make sense of alcohol use [6]. The interview and focus group data were analyzed using thematic decomposition analysis [7].

Alcohol use was consistently represented as a social activity that was heavily influenced by peers. Implicit in this construction was the notion that heavy drinking is a norm within this particular community. Although prenatal alcohol use was stigmatized, it was also understood by the pregnant women and community members as a way of dealing and coping with difficult domestic problems, such as infidelity. For some pregnant women, these problems coupled with the social nature of drinking contributed to their alcohol use throughout their pregnancy. For other pregnant women, access to social support and the desire to have a healthy baby and be a responsible mother contributed to a decision to stop drinking.

\footnotetext{
* Correspondence: janekelly88@gmail.com

Department of Psychology, University of Cape Town, Cape Town, South
} Africa

(c) 2015 Kelly and Ward; licensee BioMed Central Ltd. This is an Open Access article distributed under the terms of the Creative Commons Attribution License (http://creativecommons.org/licenses/by/4.0), which permits unrestricted use, distribution, and reproduction in any medium, provided the original work is properly cited. The Creative Commons Public Domain Dedication waiver (http://creativecommons.org/publicdomain/zero/1.0/) applies to the data made available in this article, unless otherwise stated.
Future interventions should take the social context of drinking into account, and rather than ignoring it-as most interventions do-use it to not only shift the social norms that surround heavy alcohol use, but also to support pregnant women to stop drinking. Prevention and intervention initiatives should also take a nonjudgemental and supportive approach that focuses on capitalizing on the moment of pregnancy and on teaching psychosocial skills that enable pregnant women to manage their problems effectively.

\section{Acknowledgements}

We would like to extend our thanks to the Foundation for Alcohol Related Research for providing access to the study participants and for all their support in the research process. We would also like to thank the National Research Foundation of South Africa for their financial contribution, the participants for sharing their stories, and Professor Leslie London from the University of Cape Town for originally proposing the research study.

Published: 20 February 2015

\section{References}

1. Osterman RL: Decreasing women's alcohol use during pregnancy. Alcoholism Treat Q 2011, 29:436-452.

2. May PA, Gossage JP, Kalberg WO, Robinson LK, Buckley D, Manning M, Hoyme HE: Prevalence and epidemiologic characteristics of FASD from various research methods with an emphasis on recent in-school studies. Dev Disabil Res Rev 2009, 15:176-192.

3. May PA, Blankenship J, Marais AS, Gossage JP, Kalberg WO, Barnard R, De Vries M, Robinson LK, Adnams CM, Buckley D, Manning M, Jones KL, Parry C, Hoyme HE, Seedat S: Approaching the prevalence of the full spectrum of fetal alcohol spectrum disorders in a South African population-based study. Alcohol Clin Exp Res 2013, 37:818-830.

4. Watt MH, Eaton LA, Choi KW, Velloza J, Kalichman SC, Skinner D, Sikkema KJ: "It's better for me to drink, at least the stress is going away:" Perspectives on alcohol use during pregnancy among South African women attending drinking establishments. Social Sci Medicine 2014, 116:119-125.

5. Choi KW, Abler LA, Watt MH, Eaton LA, Kalichman SC, Skinner D, Pieterse D, Sikkema KJ: Drinking before and after pregnancy recognition among South African women: The moderating role of traumatic experiences. BMC Pregnancy Childbirth 2014, 14:1-9.

6. Wilkinson S, Joffe H, Yardley L: Qualitative data collection: Interviews and focus groups. In Research Methods for Clinical and Health Psychology. London: SAGE Publications;Marks DF, Yardley L 2008:39-55. 
7. Stenner P: Discoursing jealousy. In Discourse Analytic Research: Repertoires and Readings of Texts in Action. London: Routledge;Burman E, Parker I 1993:94-132.

doi:10.1186/1940-0640-10-S1-A26

Cite this article as: Kelly and Ward: Social representations of alcohol use among women who drank while pregnant. Addiction Science \& Clinical Practice 2015 10(Suppl 1):A26.

Submit your next manuscript to BioMed Central and take full advantage of:

- Convenient online submission

- Thorough peer review

- No space constraints or color figure charges

- Immediate publication on acceptance

- Inclusion in PubMed, CAS, Scopus and Google Scholar

- Research which is freely available for redistribution

Submit your manuscript at www.biomedcentral.com/submit

() BioMed Central 